\title{
Wienbergia, new genus for Barroisia faxensis (Porifera:Demospongia) from the Middle Danian of Denmark
}

\author{
CLAUS KOCH CLAUSEN
}

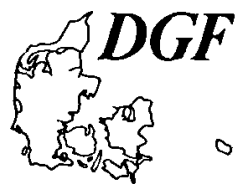

\begin{abstract}
Clausen, C. K.: Wienbergia, new genus for Barroisia faxensis (Porifera:Demospongia) from Middle Danian of Denmark. Bull. geol. Soc. Denmark, vol. 30, pp 111-115, Copenhagen, September 1st, 1982. https://doi.org/10.37570/bgsd-1981-30-11

The rare Middle Danian sponge, Barroisia faxensis Ravn, is redescribed under the new name Wienbergia faxensis. The new genus has characters which suggest that it should be placed in the order Sphinctozoida. This genus may represent a link between the Cretaceous genus Barroisia and the "living fossil" Neocoelia crypta.
\end{abstract}

Claus Koch Clausen, Institute of Historical Geology and Palaeontology, Øster Voldgade 10, 1350 Copenhagen K, Denmark. May 17th, 1982.

In 1899 Ravn described the calcareous sponge Barroisia faxensis from the coral limestone of Fakse quarry (Middle Danian, Denmark). Ravn's material consisted of 7 specimens. The recent discovery of a well preserved specimen, and comparison with a related sponge having an aspicular skeleton composed of aragonite, made a reinterpretation necessary, especially as Ravn's species so far is the only known Tertiary Sphinctozoan. Reexamination made it clear that the Fakse material does not belong to the genus Barroisia, so a new genus is created for it herein.

\section{Wienbergia n.g.}

Type species. Wienbergia faxensis nomen subst. pro Barroisia faxensis Ravn, 1899.

Diagnosis: see diagnosis of $W$. faxensis.

Derivatio nominis: In honour of the late $\mathrm{H}$. Wienberg Rasmussen.

\section{Wienbergia faxensis}

1899 Barroisia faxensis Ravn, p. 28, pl. 1, figs. 4-5.

1929 Barroisia faxensis Ravn, Voigt, p. 84.
Lectotype: MMH 15345 A \& B, figured by Ravn 1899, pl. 1, figs. 4-5.

In the present paper figs. $1,2$.

Locality of lectotype: Faxe quarry, Fakse Sjælland, Denmark.

Stratum typicum: Middle Danian, coral limestone facies. The species seems to be present in most of the sub-lithofacies of coral limestone mentioned by Floris (1979:154).

\section{Diagnosis}

Sponge, simple in outline; cylindrical; chambers subglobular to discoidal; ambisiphonate. Larger specimens are usually bent as if restricted within a cavity. The more or less marked bulges are caused by irregularities in chamber thickness. There are no signs of branching.

The surface ornamentation consists of numerous fine pores which produce a fine reticulate pattern.

The skeleton is constructed of chambers that are supported by pillars orientated perpendicular to the walls. The walls of successive chambers are closely connected. There are no spicules. 


\section{Differential diagnosis}

Wienbergia n.g. is different from the Cretaceous Barroisia by not possesing spicules in a systematic arrangement. Wienbergia n.g. differs from Neocoelia in being much larger, bending and presumably by not being branching.

\section{Relationship}

The relationship between Barroisia and related sphinctozoida has been examined by Reid (1968). He concluded that the genus Barroisia, which is restricted to the Cretaceous (England), and the closely related Tremacystia of same age, contain spicules in a systematic arrangement, and he redefined (Reid, 1968:9) these two genera on the basis of this arrangement.

In contrast, some other sphinctozoans do not possess spicules and, according to Reid (1968), this indicates that the group is polyphyletic.

Vacelet (1978) tried to solve this problem by erecting a new order, Sphaerocoelida for Cretaceous sponges having sphinctozoan structure and a skeleton of calcareous spicules, and placed this order within the Class Calcispongea. The Sphaerocoelida are thus regarded as homeomorphs of the Sphinctozoa, which Vacelet (1978) has shown to be an order of the class Demospongea.

Vacelet (1977) has described a living sphinctozoan from the Indian Ocean and New Caledonia. The skeleton of this form, Neocoelia crypta Vacelet, 1977, lacks spicules and is composed of aragonite. The living tissue lies inside the series of chambers. The histology, cytology and sexual reproduction are similar to those of the genus Ceratinomorpha in the class Demospongea (Vacelet, 1978:483).

Wienbergia faxensis shows a remarkable likeness to Neocoelia crypta in the skeletal structure, indicating close relationship.
Wienbergia n.g. is the only sphinctozoan so far known from the Tertiary and it is morphologically closely related to both Barroisia and to Neocoelia. This genus may thus represent a link between these two genera.

\section{Spicules}

Wienbergia faxensis contains no spicules and Ravn (1899:30) assumed that these had been dissolved like the rest of the skeleton. In one case (fig. 9-11) where the ubiquitous layer of cement is particularly thin and the chambers empty of sediment, the columns and the chamber wall can be seen clearly. However, close examination of these well-preserved parts has failed to reveal moulds of spicules, and it must therefore be assumed that there were none.

\section{Ecology}

Neocoelia crypta was found on the outer slope of coral reefs. The specimens occured preferentially in waterdepths of $15-38 \mathrm{~m}$., within small cavities formed by accumulation of coral debris (Vacelet, 1978). A similar habitat, associated with microcavities in coral facies, is suggested for Wienbergia faxensis.

The environments in which the limestones were deposited have been subject to lively discussion. Asgaard (1968) gave a review of the different suggestions and, partly based on the probable presence of algal borings, suggested a water depth of $50-80 \mathrm{~m}$.

Wienberg Rasmussen (1973) described a photophobic cavity-inhabiting fauna of Cyanthidium holopus growing mouth-downwards and concluded from this, and the presence of other light-shy faunal elements, that the coral limestone was formed within the photic zone.

If we may assume that the close phylogenetic relationship indicated by the morphology of

Figs. 1-6 Wienbergia faxensis n.g.

Fig. 1. Lectotype of Wienbergia faxensis n.g. MMH 15345 A, J. P. J. Ravn coll $\times 1$.

Fig. 2. Lectotype MMH 15345 B. Polished part of 15345 A showing central sipho and chambers filled with sediment. $\times 3,5$.

Fig. 3. Paralectotype from coral limestone subfacies showing well-preserved moulds of pillars in the right part. J. P. J. Ravn coll. $\times 1,7$. Fig. 4. Paralectotype less well-preserved but in parts showing distinct ornamentation. $\times 1,7$.

Fig. 5-6. Well preserved specimen showing details of the structure. P. C. Toft coll. Fig. 9-11 stems from the extreme left part of this specimen (fig. 5). Fig. $5 \times 1,5$, fig. $6 \times 2$. 

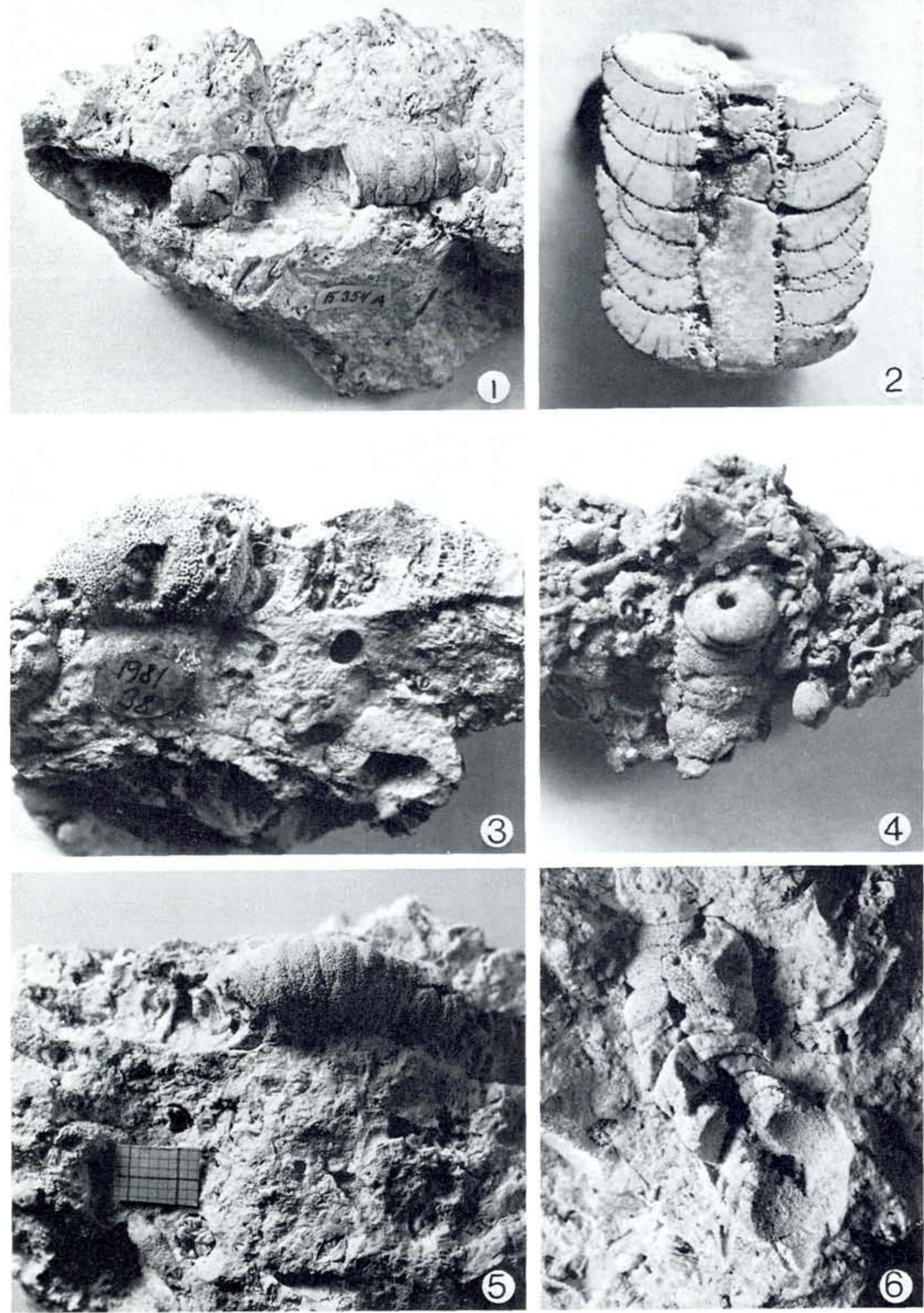
Wienbergia faxensis and Neocoelia crypta represents a basis for assuming a similarity of life habit, then the presense of $W$. faxensis at Faxe might be taken to indicate a water depth closer to 50 than $80 \mathrm{~m}$.

Acknowledgements. Peter Christian Toft provided the new specimen and Richard G. Bromley, Ole Tendal and Ulla Asgaard gave valuable criticism of the manuscript. SEM pictures were made by the Electron Micrescopy Laboratory of the Geological Central Institute.

\section{Dansk sammendrag}

Den sjaldne svamp fra Faxe kalkbrud, Barroisia faxensis er genbeskrevet under det nye navn Wienbergia faxensis. Arten syntes repræsenteret i flere af de lithofacies der findes i koralkalken. Undersøgelse af meget velbevarede dele viser ingen spor efter spikler og det antages derfor at Wienbergia n.g. ikke havde spikler. Skeletopbygningen er meget lig Neocoelia crypta, en nulevende sphinctozo uden spikler, der er fundet på den ydre kant af koralrev, i små hulrum i koraldebris. Wienbergia er indtil videre den eneste kendte tertiære sphinctozo og er således måske bindeled mellem Barroisia fra kridttiden og den nulevende Neocoelia crypta.

\section{References}

Asgaard, U. 1968. Brachiopod palaeoecology in Middle Danian limestones at Fakse, Denmark. Lethaia, 1, 103-121.

Floris, S. 1979. Guide to Fakse Limestone Quarry. In Birkelund, T. \& Bromley, R. G. (eds): 1. The Maastrichtian and Danian of Denmark, 152-163. Cretaceous-Tertiary Boundary events Symposium, University of Copenhagen, 1979.

Goldfuss, H. 1831. Petrefacta Germaniae, Lief. 3, p. 220. Arnz, Düsseldorf.

Rasmussen, H. W. 1973. En lyssky hulefauna fra Fakse som vidnesbyrd om koralkalkens dannelse i lyszonen. Dan. geol. Foren. Arsskr. 1972, 87-91.

Ravn, J. P. J. 1899. Et par danske Kridtspongier. Meddr. dan. geol. Foren., 1(5), 24-32.

Reid, R. E. H. 1968. Tremacystia, Barroisia and the status of Sphinctozoida (Thalamida) as porifera. Univ. Kansas paleont. Contr., 34, 1-10.

Vacelet, J. 1977. Une nouvelle relique du secondaire: un representant actuel des éponge fossile Sphinctozoaires. Compts rend. Acad. Sci. Paris, 285, 509-511.

Vacelet, J. 1978. Description et affinities d'une éponge sphinctozoaire actuelle. In: Levi, C. \& Boury-Esnault, N. (Eds.) Biologie des Spongiaires. Colloques internationaux C.N.R.S. No. 291, 483-493.

Voigt, E. 1929. Der Lithogenese der Flach- und Tiefwassersedimente des jüngeren Oberkreidemeeres. Jahrb. Halleschen Verb. Erforsh. mitteldeutsch. Bodenschätze u. ihre Verwertung, 8, 1-136.

Figure 7-11. Sem-pictures of Wienbergia axensis t..g. showing details of structure. P. C. Toft coll.

Fig. 7. Details of part of the structure showing chambers supported by pillars orientated perpendicular to the walls. $\times 15$.

Fig. 8. Closeup of moulds after walls between two chambers showing the close connecting. $\times 110$.

Fig. 9. Well-preserved part of the specimen showing a thin layer of ubiquitous cement. There are no sign of moulds after spicules. $\times 65$.

Fig. 10. Closeup view of connection between two pillars. $\times 220$.

Fig. 11. Internal view into the mould of one of the pillars. $\times 900$ 

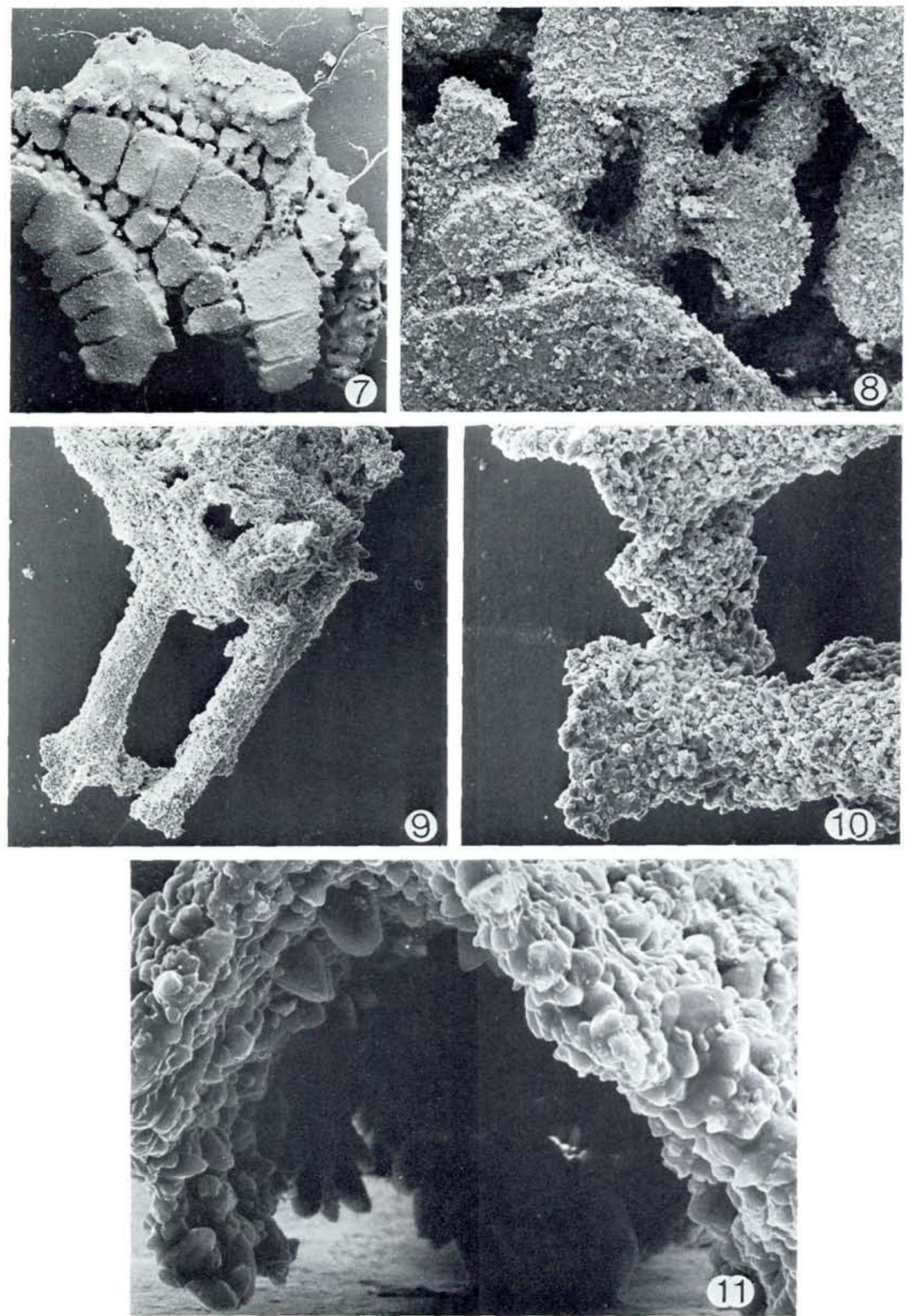